\title{
中庸熱ポルトランドセメントを用いた高強度コンクリ 一トの諸性状および構造体強度と水セメント比の関係
}

\author{
秋里紅路*1 $・$ 藤井和俊 $* 2 \cdot$ 鳴瀬浩康 ${ }^{* 3} \cdot$ 毛見虎雄 $* 4$
}

\begin{abstract}
概 要 本研究は, これまでマスコンクリートに適用される機会が多かった中庸熱ポルトランドセメントを, 設計基準 強度 $36 \sim 70 \mathrm{~N} / \mathrm{mm}^{2}$ の高強度コンクリートに適用した場合のフレッシュ性状, 実大模擬柱部材の温度履歴性状および強 度発現性状について考察したものである。その結果, 中庸熱ポルトランドセメントを用いた高強度コンクリートは, 現 場において十分に施工可能であることが分かった。また, 単位セメント量と打込み時のコンクリート温度に基づく実大 模擬柱部材の最高温度の推定式, 簡易断熱養生強度とコア強度の関係式および柱部材における構造体コンクリート強度 が設計基準強度を満足するための水セメント比を提案した。
\end{abstract}

キーワード: 中庸熱ポルトランドセメント, 高強度コンクリート, フレッシュ性状, 圧縮強度, 水セメント比, 施工性

\section{1.はじめに}

近年, 超高層 RC 造集合住宅に適用される高強度コンク リートの需要は, 増加の一途をたどっている。1997 年以 降, 設計基準強度 $36 \mathrm{~N} / \mathrm{mm}^{2}$ を超え $60 \mathrm{~N} / \mathrm{mm}^{2}$ 以下の範囲の コンクリートは汎用的な高強度コンクリートの領域とし て認識されつつあり, 設計基準強度 $60 \mathrm{~N} / \mathrm{mm}^{2}$ を超える建 築物の実績も豊富になってきている。この様な領域の高 強度コンクリート用セメントとしての普通ポルトランド セメントは，設計基準強度 $60 \mathrm{~N} / \mathrm{mm}^{2}$ 級までは十分に適用 可能といえる。しかし, 品質上からの強度発現性や施工 性確保の観点から, 設計基準強度が $50 \mathrm{~N} / \mathrm{mm}^{2}$ を超えるコ ンクリートでは，低熱ポルトランドセメントを使用する ことが多い11。

低熱ポルトランドセメントを用いた高強度コンクリー トは，普通ポルトランドセメントを用いた場合と比較し て, 高温環境下における諸性状は極めて優れている ${ }^{2)} も$ のの，低温環境下では凝結時間の遅延が大きく，若材齢 の強度発現も小さい3)。これらは，実施工において，特 に建築工事に係わる表面仕上げの開始時間や型枠の取外 し時期といった工程管理にも影響を及ぼす可能性がある。

今後は，これまでの実績をふまえた上で，構造体強度 の確保，施工性および経済性に対して更なるバランスの とれた高強度コンクリートの強度領域に対応したセメン トなどの材料選定が重要となると考えられる。特に，コ ンクリートの材料としては, 入手が比較的容易で安定的
に供給され，可能な限り安価であることが望まれる。 一方, 様々な面で, 普通ポルトランドセメントと低熱 ポルトランドセメントの中間的な位置付けにあると考え られる中庸熱ポルトランドセメントは，とりわけ，その 熱的性質や強度発現性からマスコンクリートに適用され てきた。近年，建築構造物も部材が大きく高強度が要望 されていることから，中庸熱ポルトランドセメントのこ れらへの適用が期待される。しかしながら，これを実際 に高強度コンクリートに使用した場合のフレッシュ性状 および強度発現性などの諸性状や構造体コンクリート強 度と水セメント比の関係に関する報告は極めて少ない。

そこで本研究は, 中庸熱ポルトランドセメントを設計 基準強度 $36 \sim 70 \mathrm{~N} / \mathrm{mm}^{2}$ の高強度コンクリートに適用し た場合のフレッシュ性状, 実大模擬柱部材の温度履歴性 状および強度発現性について検討した結果に基づき, 構 造体コンクリート強度 (コア強度) が設計基準強度を満足 するための水セメント比とその施工性について考察した。 なお，本論文の一部は文献 ${ }^{7)}$ に発表している。

\section{2. 中庸熱ポルトランドセメントの性質と用途}

中庸熱ポルトランドセメントは, 水和熱が低く, また, 鉱物組成では $\mathrm{C}_{3} \mathrm{~A}$ 量が少ないという特徵を持つ。このた め, 中庸熱ポルトランドセメントを使用したコンクリー トは温度上昇が小さい, 乾燥収縮が小さい, 化学的抵抗 性が大きいといった性能を有し，用途的にはマスコンク 
表一 1 各種セメントの物理化学的性質

\begin{tabular}{|c|c|c|c|c|c|c|c|c|c|c|c|c|c|c|c|}
\hline \multirow{3}{*}{$\begin{array}{l}\text { セメント } \\
\text { 種類 }\end{array}$} & \multicolumn{11}{|c|}{ 物理的性質 } & \multicolumn{4}{|c|}{ 鉱物組成 (\%) } \\
\hline & \multirow{2}{*}{$\begin{array}{l}\text { 密度 } \\
\left(\mathrm{g} / \mathrm{cm}^{3}\right)\end{array}$} & \multirow{2}{*}{$\begin{array}{c}\text { 比表面積 } \\
\left(\mathrm{cm}^{2} / \mathrm{g}\right)\end{array}$} & \multicolumn{2}{|c|}{ 凝結（h-min） } & \multicolumn{4}{|c|}{ 圧縮強さ $\left(\mathrm{N} / \mathrm{mm}^{2}\right)$} & \multicolumn{3}{|c|}{ 水和熱 $(\mathrm{J} / \mathrm{g})$} & \multirow{2}{*}{$\mathrm{C}_{3} \mathrm{~S}$} & \multirow{2}{*}{$\mathrm{C}_{2} \mathrm{~S}$} & \multirow{2}{*}{$\mathrm{C}_{3} \mathrm{~A}$} & \multirow{2}{*}{$\mathrm{C}_{4} \mathrm{AF}$} \\
\hline & & & 始発 & 終結 & 3日 & 7日 & 28日 & 91日 & 7 日 & 28日 & 91日 & & & & \\
\hline \multirow{2}{*}{$\mathrm{N}$} & 3.16 & 3290 & $2-20$ & $3-35$ & 26.9 & $\overline{42.8}$ & 60.5 & 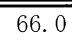 & 327 & $\overline{380}$ & 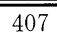 & $\overline{56}$ & 18 & 10 & 8 \\
\hline & (3.15) & $(3410)$ & $(2-16)$ & $(3-13$ & $(28.0)$ & $(43.1)$ & (61.3) & & & & & (57) & (18) & (9) & (9) \\
\hline \multirow{2}{*}{ M } & 3.21 & 3480 & $2-45$ & $4-15$ & 20.2 & 29.3 & 58.8 & 73.6 & 266 & 314 & 364 & 40 & 39 & 4 & 10 \\
\hline & $(3.22)$ & $(3220)$ & $(3-02)$ & $(4-07$ & $(21.6)$ & $(30.3)$ & $(56.8)$ & & $(267)$ & (322) & & (49) & (29) & (3) & (12) \\
\hline & 3.22 & 3780 & $2-45$ & $4-00$ & 16.4 & 25.2 & 57.4 & 74.5 & 220 & 280 & 331 & 32 & 50 & 3 & 9 \\
\hline & $(3.21)$ & $(3470)$ & $(3-30)$ & $(4-42)$ & (16.2) & $(25.3)$ & $(49.0)$ & $(79.1)$ & $(226)$ & (275) & & $(31)$ & $(52)$ & (3) & (8) \\
\hline
\end{tabular}

上段は今回使用したセメントの技術資料 ${ }^{4)}$ による。下段 (カッコ内) は文献による品質の一例 ${ }^{5}$

リート構造物に使用される場合が

多い。普通 $(\mathrm{N})$, 中庸熱 $(\mathrm{M})$ および 低熱 (L) ポルトランドセメントの 物理化学的性質の一例4)，5) を表 - 1に示す。中庸熱ポルトランド セメントの性質は, ほとんどの項 目において, 普通ポルトランドセ メントと低熱ポルトランドセメン トのほぼ中間にあることがわかる。 中庸熱ポルトランドセメントは 低熱ポルトランドセメントに比べ $\mathrm{C}_{2} \mathrm{~S}$ 量が $10 \%$ 以上少なく, 水和熱 は低熱ポルトランドセメントほど 低くないものの, その分初期強度 の発現性などは相対的に高く, 高強度コンク リート用としてはバランスのとれたセメント といえる。最近, 建築分野での超高層 RC 建 築においては, 地中梁や柱部材が高強度コン クリートを使用したマスコンクリートになる ことが多い。これまで一般的に高炉セメント B 種や普通ポルトランドセメントが使用され てきたが，この種の構造物にも中庸熱ポルト ランドセメントの使用が増加してきている。

\section{3. 実験概要}

\section{1 試験項目および試験方法}

試験項目および試験方法を表一 2 に示す。 圧縮強度試験用供試体の採取時期は, 練混ぜ から 30 分経過時におけるフレッシュ性状確認 後とした。試験は，東京都内にある A, B, C の 3 工場で夏期 ・標準期 ・ 冬期について各工場 で行い, 試験項目はできるだけ統一し, 凝結 試験とL型フロー試験のみ一部割愛した。

\section{2 使用材料と調合}

コンクリートの使用材料を表一 3 に, 計画 調合を表一 4 に示す。 3 工場の中で, A 工場に ついては, 最初に実施した水セメント比の範 囲 (1) を拡大するために追加実験 (2) を行っ

表 -2 試験項目および試験方法

備考

時変化試験

$(0,30,60,90,120$ 分 $)$

フロー初速度 空気量 リーデイング量 凝結時間

\begin{tabular}{|c|c|c|c|c|c|}
\hline 11 & 0 & 0 & 0 & 0 & 淐度計に一る \\
\hline TTC 110 & 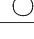 & 0 & 0 & 0 & 温度計による \\
\hline 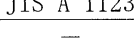 & - & 0 & U & 0 & 何訨し地㷛（住外 \\
\hline
\end{tabular}

\begin{tabular}{|c|c|c|c|l|l} 
& - & $\bigcirc$ & $\bigcirc$ & $\bigcirc$ & CFT構造技術指針 $^{11)}$ による \\
\hline JIS A 1147 & - & - & - & $\bigcirc$ & 荷卸し地点 $($ 屋外)
\end{tabular}

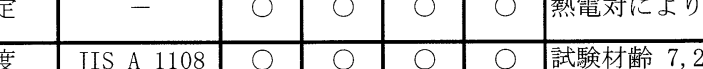

\begin{tabular}{l|l} 
コア強度 & JIS A 1108 \\
\hline
\end{tabular}

\begin{tabular}{l|l} 
& JIS A 1107 \\
&
\end{tabular}

易断熱養生強度

: 実施せず

\begin{tabular}{|c|c|c|}
\hline 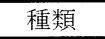 & 工場 & 産地・性質 \\
\hline セメント & $A, B, C$ & $\begin{array}{l}\text { 中庸熱ポルトランドセメント } \\
\text { 密度 } 3.21 \mathrm{~g} / \mathrm{cml}^{3} \text {, 比表面積 } 3480 \mathrm{~cm}^{2} / \mathrm{g}, \quad \mathrm{C}_{2} \mathrm{~S} \text { 量 }=39 \%\end{array}$ \\
\hline 練混ぜ水 & $\mathrm{A}, \mathrm{B}, \mathrm{C}$ & 上水道水 \\
\hline \multirow{3}{*}{ 細骨材 } & A & 君津産山砂 : 表乾密度 $2.56 \mathrm{~g} / \mathrm{cm}^{3}$, 粗粒率 2.65 \\
\hline & B & $\begin{array}{l}\text { 富津産陸砂・八戸産砕砂の混合砂 }(60: 40) \\
\text { 表乾密度 } 2.60 \mathrm{~g} / \mathrm{cm}^{3}, \text { 粗粒率 } 2.60\end{array}$ \\
\hline & $\mathrm{C}$ & $\begin{array}{l}\text { 君津産山砂 : 表乾密度 } 2.56 \mathrm{~g} / \mathrm{cm}^{3} \\
\text { 田沼産砕砂 : 表乾密度 } 2.60 \mathrm{~g} / \mathrm{cm}^{3} \\
\text { 混合砂の粗粒率 } 2.60 \text { (山砂 : 砕砂 }=70 \%: 30 \% \text { ) }\end{array}$ \\
\hline \multirow{3}{*}{ 粗骨材 } & A & 鳥形山産石灰砕石：表乾密度 $2.69 \mathrm{~g} / \mathrm{cm}^{3}$, 実積率 $60.0 \%$ \\
\hline & B & $\begin{array}{l}\text { 伊佐産石灰砕石: 表乾密度 } 2.67 \mathrm{~g} / \mathrm{cm}^{3} \\
\text { 八戸産石灰砕石: 表乾密度 } 2.69 \mathrm{~g} / \mathrm{cml}^{3} \\
\text { 実積率 } 61.0 \% \text { (伊佐 : 八戸 }=70 \%: 30 \% \text { ) }\end{array}$ \\
\hline & $\mathrm{C}$ & 伊佐産石灰砕石：表乾密度 $2.69 \mathrm{~g} / \mathrm{cm}^{3}$, 実積率 $61.0 \%$ \\
\hline \multirow{3}{*}{$\begin{array}{l}\text { 高性能 } \\
\mathrm{AE} \\
\text { 減水剂 }\end{array}$} & A & 末端スルホン酸基を有するポリカルボン酸基含有多元ポリマー \\
\hline & B & ポリカルボン酸エーテル系化合物と分子架橋ポリマーの複合体 \\
\hline & $\mathrm{C}$ & カルボキシル基含有ポリエーテル系 \\
\hline
\end{tabular}

表－4 コンクリートの計画調合

\begin{tabular}{|c|c|c|c|c|c|c|c|c|c|c|c|}
\hline \multirow{2}{*}{\multicolumn{2}{|c|}{ 工場 }} & \multirow[b]{2}{*}{ 記号 } & \multirow{2}{*}{$\begin{array}{l}\text { W/C } \\
(\%)\end{array}$} & \multirow{2}{*}{$\begin{array}{l}\mathrm{s} / \mathrm{a} \\
(\%)\end{array}$} & \multirow{2}{*}{$\begin{array}{c}\text { 目標 } \\
\text { スランプフロ } \\
(\mathrm{cm})\end{array}$} & \multirow{2}{*}{$\begin{array}{c}\text { 目標 } \\
\text { 空気量 } \\
(\%)\end{array}$} & \multicolumn{4}{|c|}{ 単位量 $\left(\mathrm{kg} / \mathrm{m}^{3}\right)$} & \multirow{2}{*}{$\begin{array}{c}\mathrm{Ad} \\
(\mathrm{C} \times \%)\end{array}$} \\
\hline & & & & & & & $W$ & $C$ & $S$ & $G$ & \\
\hline \multirow{6}{*}{ A } & \multirow{3}{*}{ (1) } & A38 & 37.9 & 52.4 & $55 \pm 7.5$ & \multirow{3}{*}{$\begin{array}{c}2.0 \\
\pm 1.5\end{array}$} & \multirow{3}{*}{165} & 436 & $\overline{9926}$ & 873 & 1.30 \\
\hline & & A 34 & 33.6 & 51.2 & $60 \pm 10$ & & & 492 & 881 & 873 & 1.20 \\
\hline & & A 29 & 29.3 & 49.5 & $65+5,-10$ & & & 564 & 822 & 873 & 1.20 \\
\hline & \multirow{3}{*}{ (2) } & $\mathrm{A} 45$ & 45.0 & 53.8 & $55 \pm 7.5$ & \multirow{3}{*}{$\begin{array}{c}3.0 \\
\pm 1.5\end{array}$} & \multirow{3}{*}{165} & 367 & 967 & 864 & 1.10 \\
\hline & & A 40 & 40.0 & 52.7 & $55 \pm 7.5$ & & & 413 & 926 & 864 & 1.10 \\
\hline & & A 35 & 35.0 & 51.4 & $55 \pm 7.5$ & & & 472 & 879 & 864 & 1.10 \\
\hline & B 45 & 45.0 & 50.5 & $50 \pm 7.5$ & \multirow{3}{*}{$\begin{array}{l}3.0 \\
\pm 1.5\end{array}$} & \multirow{3}{*}{165} & 367 & 914 & 920 & 1.20 \\
\hline & & B 34 & 34.0 & 48.5 & $55 \pm 7.5$ & & & 486 & 833 & 904 & 1.40 \\
\hline & & B 27 & 27.0 & 47.4 & $60 \pm 10$ & & & 612 & 762 & 869 & 1.90 \\
\hline \multirow{3}{*}{\multicolumn{2}{|c|}{ C }} & C 48 & 48.0 & 50.0 & $50 \pm 7.5$ & \multirow{3}{*}{$\begin{array}{c}2.0 \\
\pm 1.5\end{array}$} & \multirow{3}{*}{170} & 354 & 996 & 847 & 1.60 \\
\hline & & C 38 & 38.0 & 53.1 & $60 \pm 10$ & & & 447 & 920 & 847 & 1.65 \\
\hline & & $\mathrm{C} 28$ & 28.0 & 49.3 & $60 \pm 10$ & & & 607 & 846 & 847 & 1.80 \\
\hline
\end{tabular}


た。計画調合におけるスランプフローの目標值は，各工 場の実績を考慮した上で，良好なワーカビリティーが得 られるように室内試し練りにより定めた。空気量の目標 值は，凍害を受けるおそれのない地域で使用することを 前提に $2.0 \%$ または $3.0 \%$ とした。

なお，本実験は，高強度コンクリートが新たに規定さ れた JIS A 5308 : 2003 (レディーミクストコンクリート) の改訂以前に実施したものである。

\section{3 実大模擬柱試験体}

実大模擬柱試験体の形状およびコア採取位置を図ー 1 に示す。

\section{4 コンクリートの製造・打込み}

コンクリートの練混ぜ量と練混ぜ時間を表一 5 に示す。 練混ぜは, 強制二軸ミキサで行い, 材料一括練りとした。 練混ぜ時間は，水セメント比が小さくなるにしたがって 長く設定し，ミキサの負荷電流が安定するまでとした。

実大模擬柱試験体へのコンクリートの打込みは, 練混 ぜから 30 分経過時とし, 高さ $55 \mathrm{~cm}$ 毎に棒状バイブレー 夕を用いて $5 \sim 10$ 秒間挿入して締固めた。

\section{5 簡易断熱養生供試体の製作 ${ }^{71}$}

簡易断熱養生供試体は， $\phi 10 \mathrm{~cm} \times 20 \mathrm{~cm}$ の軽量モールド にコンクリートをつめてポリエチレンフィルムとビニー ルテープで封かんした後, 図ー2 に示す厚さ $200 \mathrm{~mm}$ の発 泡ポリスチレン製の容器に設置し，その際生じた隙間に は発泡ビーズを充填した。その後容器内で 7 日間養生し, 以降は試験材齢まで現場封かん養生とした。

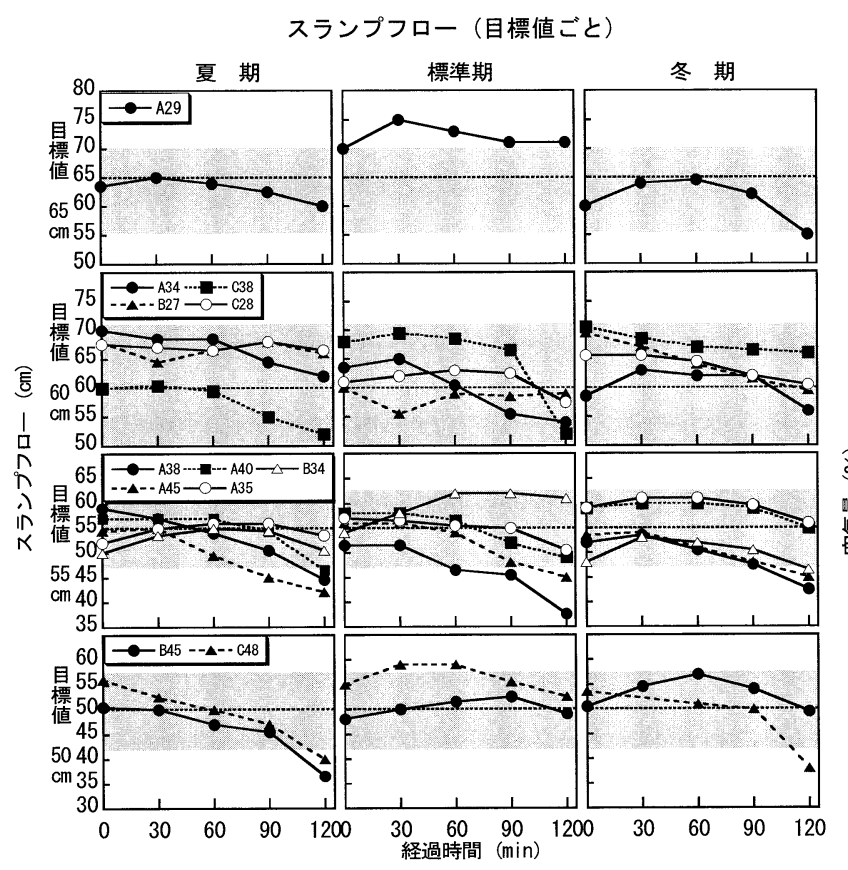

図ー3 スランプフローおよび空気量の経時変化

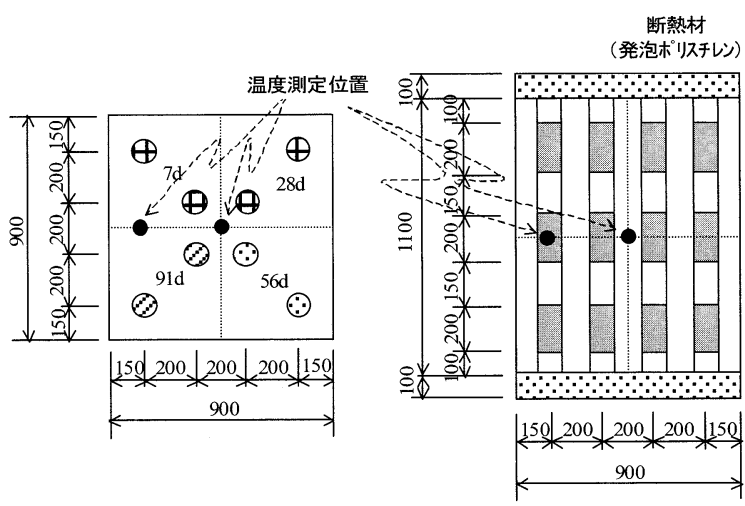

図-1 実大模擬柱試験体の形状とコア採取位置（単位 mm）

\begin{tabular}{|c|c|c|c|c|c|c|c|c|}
\hline \multirow{2}{*}{ 工場 } & \multirow{2}{*}{\multicolumn{2}{|c|}{ (1) }} & \multirow{2}{*}{\multicolumn{2}{|c|}{ A }} & \multirow{2}{*}{\multicolumn{2}{|c|}{ B }} & \multirow{2}{*}{\multicolumn{2}{|c|}{ C }} \\
\hline & & & & & & & & \\
\hline $\begin{array}{c}\text { ミキサ容量 } \\
\left(\mathrm{m}^{\mathrm{s}}\right)\end{array}$ & \multicolumn{2}{|c|}{6.0} & \multicolumn{2}{|c|}{6.0} & \multicolumn{2}{|c|}{3.0} & \multicolumn{2}{|c|}{3.0} \\
\hline $\begin{array}{c}\text { 練混ぜ量 } \\
\left(\mathrm{m}^{2} \text { ) }\right.\end{array}$ & \multicolumn{2}{|c|}{$2.0 \times 2$} & \multicolumn{2}{|c|}{$2.0 \times 2$} & \multicolumn{2}{|c|}{$2.5 \times 2$} & \multicolumn{2}{|c|}{$2.0 \times 2$} \\
\hline \multirow{3}{*}{$\begin{array}{c}\text { 練混ぜ時間" } \\
\text { ( s ) }\end{array}$} & A38 & 50 & A 45 & 40 & B45 & 40 & C48 & 60 \\
\hline & A34 & 60 & A 40 & 40 & B 34 & 60 & C 38 & 90 \\
\hline & A 29 & 60 & A 35 & 50 & B 27 & 90 & C 28 & 120 \\
\hline
\end{tabular}

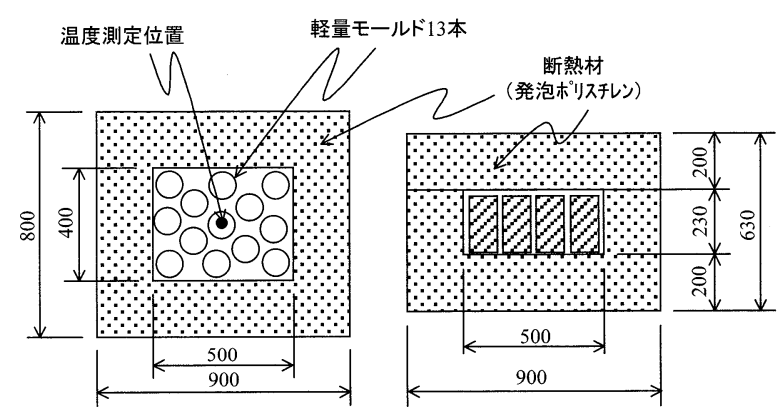

図一 2 簡易断熱養生容器と供試体 (単位 : mm)

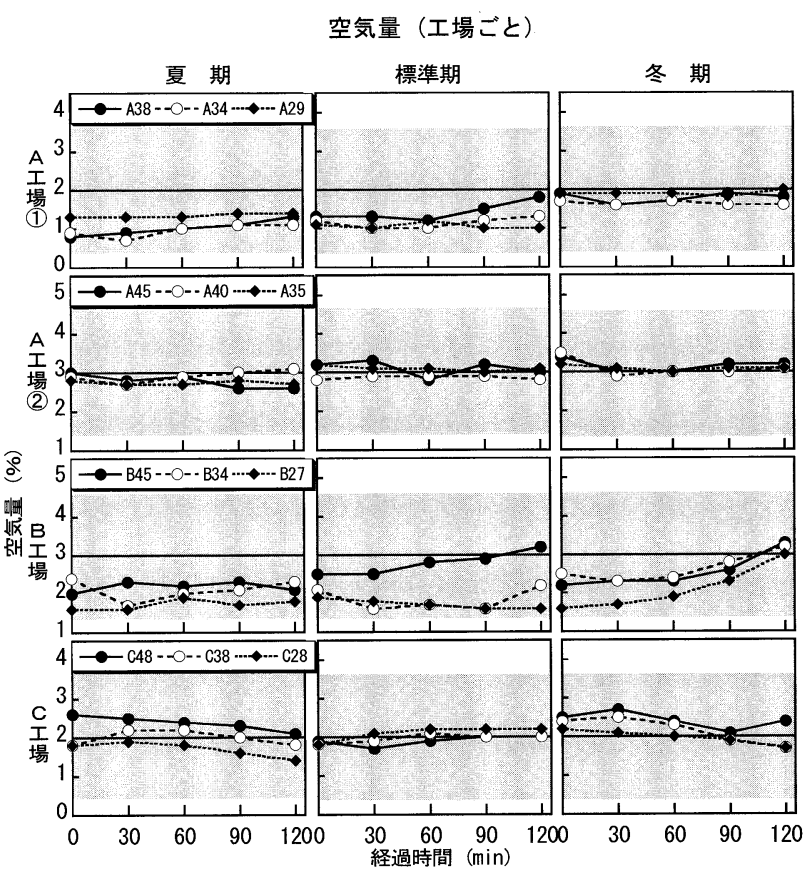

目標值に対する許容範囲) 


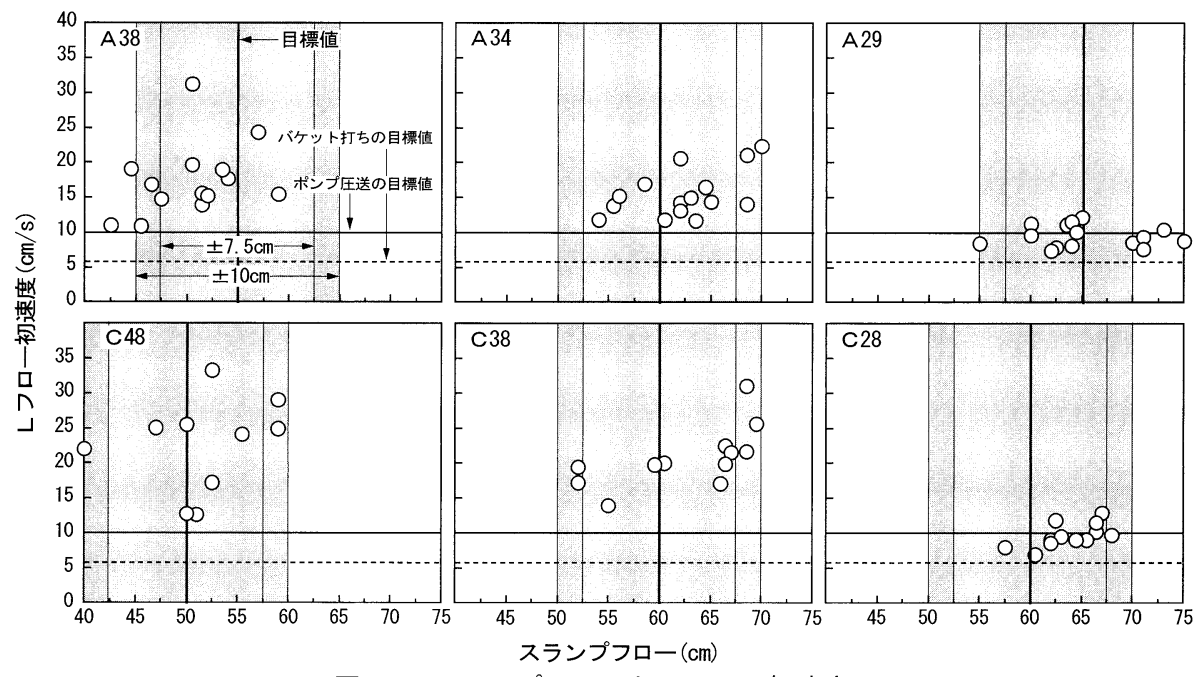

図ー4 スランプフローとしフロー初速度

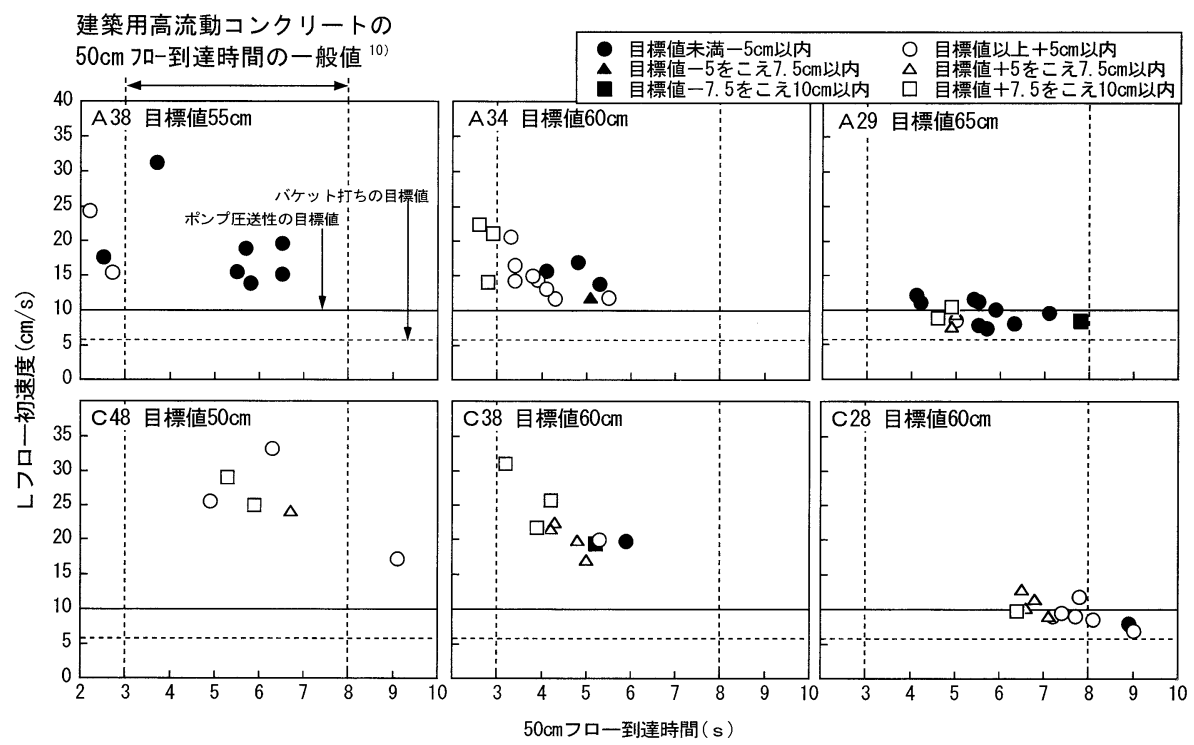

図ー $550 \mathrm{~cm}$ フロー到達時間と レフロー初速度

\section{4. 実験結果と考察}

\section{1 フレッシュコンクリートの性状}

（1）スランプフローおよび空気量の経時変化

スランプフローおよび空気量の経時変化の結果を図一 3 に示す。スランプフローの経時変化量は, 練混ぜから 90 分後では最大で $-9.5 \mathrm{~cm}(\mathrm{~A} 45), 120$ 分後では最大で $-16 \mathrm{~cm}(\mathrm{C} 48, \mathrm{C} 38)$ であった。打込み時期による比較では夏 期が，水セメント比では大きな調合のスランプフローの 低下が顕著であった。また，水セメント比 $29.3 \%$ 調合 (A29)では，スランプフローが $70 \mathrm{~cm}$ をこえたが，その場 合でも分離などみられず，良好な状態であった。空気量 は，一部の調合で，増加傾向がみられたが，いずれも 120 分まで目標値を満足した。

（2）スランプフローとLフロー初速度

スランプフローとLフロー初速度の関係を図ー4に示 す。L形フロー試験は，コンクリートの粘性評価の一手 法であり, この試験により求まるLフロー初速度は, 現
場施工可能なワーカビリティー評価の指標となる。その 目標値は通常の範囲におけるポンプ圧送の場合で $10 \mathrm{~cm} / \mathrm{s}$ 以上，バケット打ちの場合で $6 \mathrm{~cm} / \mathrm{s}$ 以上に設定されてい る $^{8)}$ 。

Lフロー初速度は，全ての調合において，バケット打 ちの目標值 $(6 \mathrm{~cm} / \mathrm{s}$ 以上) を満足する結果であった。

水セメント比で比較すると，33.6〜 48\%までの範囲 （A29, C28 を除く全て）におけるLフロー初速度は，スラ ンプフローが目標值に対して $-10 \mathrm{~cm}$ 程度であっても $10 \mathrm{~cm} / \mathrm{s}$ 以上の結果が得られており，この範囲の水セメント比で は，JASS 5 に規定されている高強度コンクリートのスラ ンプフローの許容範囲内であれば, 所要のポンプ圧送性 は確保できると考えられる。

なお，ポンプ圧送性については，25階建ての高層 RC 集合住宅の実施工に先立ち, A38 調合を用いてポンプ圧 送性実験を行い，その圧送性能および圧送前後のコンク リートのスランプフロー, 空気量および圧縮強度の確認 を行っている ${ }^{9)}$ 。その際，水平管内圧力損失 $\mathrm{K}$ の值は, 
$0.007 \sim 0.013 \mathrm{~N} / \mathrm{mm}^{2} / \mathrm{m}$ であり, Lフロー初速度が $10 \mathrm{~cm} / \mathrm{s}$ 以上であれば，高さ $50 \mathrm{~m}$ の高所圧送が可能であった。

水セメント比 $30 \%$ 未満の調合 $(A 29, C 28)$ では, スラン プフロー值にかかわらず，Lフロー初速度はほぼ一定の 値を示した。特に, スランプフロー值が $65 \mathrm{~cm}$ を超える場 合であっても, Lフロー初速度は $10 \mathrm{~cm} / \mathrm{s}$ 前後であるため, 水セメント比が $30 \%$ 未満となる調合のポンプ圧送を行う にあたっては事前に圧送実験などにより, 圧送の適否に ついて十分な検討を行う必要があると考えられる。

（3） $50 \mathrm{~cm}$ フロー到達時間と Lフロー初速度

$50 \mathrm{~cm}$ フロー到達時間と Lフロー初速度の関係を図ー 5 に示す。全体として $50 \mathrm{~cm}$ フロー到達時間が長くなると ともにLフロー初速度は小さくなる傾向が認められるが, そのばらつきは大きく, 調合条件による影響が大きい結 果となった。

水セメント比で比較すると, $30 \%$ 未満の調合 (A29, C28) の $50 \mathrm{~cm}$ フロー到達時間は, スランプフローが大きくなる に従って，短くなる傾向にあるが，Lフロー初速度はほ ぼ一定の值を示した。

水セメント比の範囲が 33.6〜 48\%の中で, スランプフ ローの目標值が $60 \mathrm{~cm}$ の調合 (A34, C38)では，スランプフ ロー值が大きくなるに従って, $50 \mathrm{~cm}$ フロー到達時間は短 く，Lフロー初速度が大きくなる傾向にあった。

スランプフローの目標值が $50 \mathrm{~cm}$ および $55 \mathrm{~cm}$ の調合 (A38,C48)では，スランプフロー值， $50 \mathrm{~cm}$ フロー到達時 間およびLフロー初速度の関係に明確な傾向は見られな かった。この理由として，A38 およびC48 調合における 経過時間ごとのスランプフロー試験結果には $50 \mathrm{~cm}$ に満た ない結果が半数近く含まれていたことなどが原因と考え られる。

スランプフローの目標值が $60 \mathrm{~cm}$ 以上の調合 $(\mathrm{A} 38, \mathrm{C} 48$ を除く全て)における $50 \mathrm{~cm}$ フロー到達時閒と L フロー初 速度の関係を図ー 6 に示す。スランプフローの目標值が $60 \mathrm{~cm}$ 以上の調合では, 実施工場別によるLフロー初速度 と $50 \mathrm{~cm}$ フロー到達時間に高い相関性があり, L フロー初 速度 $10 \mathrm{~cm} / \mathrm{s}$ に対応する $50 \mathrm{~cm}$ フロー到達時間はいずれも 約 6〜7 秒と既往の研究 ${ }^{8)}$ と同様の傾向を示した。この ことから, 中庸熱ポルトランドセメントを用いた高強度 コンクリートの実施工における粘性評価は, 各種セメン トを用いた場合と同様に, $50 \mathrm{~cm}$ フロー到達時間による管 理も可能と考えられる。

(4) 凝結

凝結試験結果を図ー7に示す。凝結の始発時間は, 同 一水セメント比ではコンクリート温度が高いほど, 同一 打込み時期では水セメント比が小さいほど早い結果と なった。また, 全ての調合で, 高流動コンクリートの凝 結時間の規定值(始発 20 時間以内 ${ }^{10)}$ を十分に満足した。

（5）ブリーディング量および沈降量

ブリーディング量および沈降量試験結果を表ー 6 に示

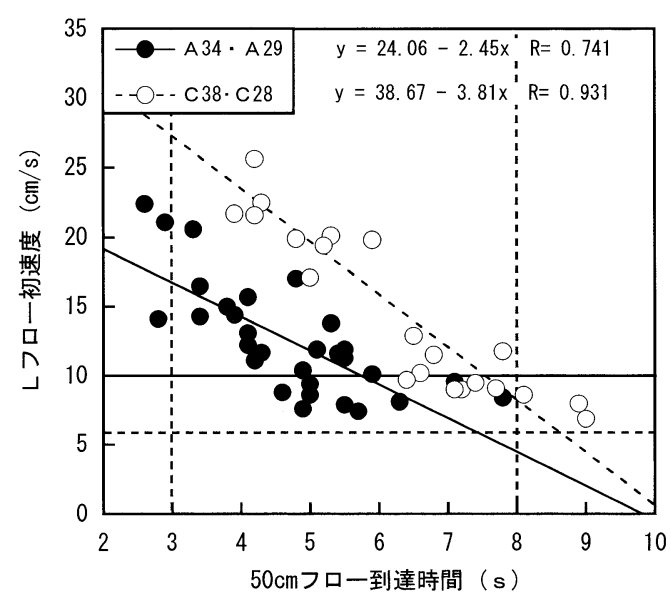

図ー6 $50 \mathrm{~cm}$ フロー到達時間とレフロー初速度 （目標スランプフロー $60 \mathrm{~cm}$ 以上）

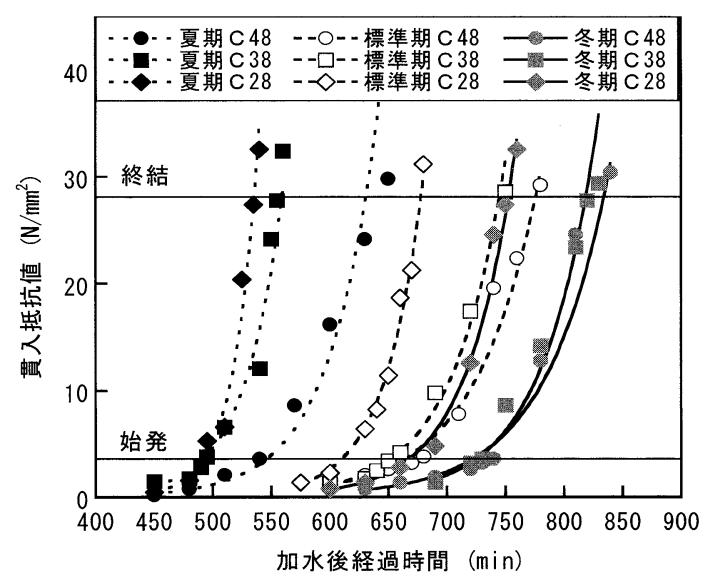

図一 7 凝結試験結果

表一 6 ブリーディング量と沈降量

\begin{tabular}{|c|c|c|c|c|c|c|}
\hline \multirow{2}{*}{ 記号 } & \multicolumn{3}{|c|}{ ブリーデ价グ量 $\left(\mathrm{cm}^{3} / \mathrm{cm}^{2}\right)$} & \multicolumn{3}{|c|}{ 沈降量 $(\mathrm{mm})$} \\
\hline & 夏期 & 標準期 & 冬期 & 夏期 & 標準期 & 冬期 \\
\hline A38 & 0.01 & 0.07 & 0.05 & 1.11 & 0.90 & 0.38 \\
\hline A 34 & 0 & 0.04 & 0.04 & 1.02 & 0.80 & 0.53 \\
\hline A 29 & 0 & 0.02 & 0.01 & 1.02 & 1.00 & 0.52 \\
\hline B 45 & 0 & 0.02 & 0.04 & 0.40 & 0.50 & 0.20 \\
\hline $\mathrm{B} 40$ & 0 & 0 & 0.01 & 0.40 & 0.60 & 0.10 \\
\hline B 35 & 0 & 0 & 0 & 0.50 & 0.60 & 0.30 \\
\hline $\mathrm{C} 48$ & 0 & 0.02 & 0.01 & 0.92 & 0.84 & 1.04 \\
\hline C 38 & 0 & 0 & 0.01 & 0.67 & 0.99 & 0.80 \\
\hline C 28 & 0 & 0 & 0 & 1.05 & 0.80 & 0.55 \\
\hline
\end{tabular}

す。荷卸し地点におけるブリーデイング量と沈降量は, 全ての調合において CFT 構造技術指針・同解説 ${ }^{11)}$ の規定 值 (ブリーディング量 $\leqq 0.1 \mathrm{~cm}^{3} / \mathrm{cm}^{2}$, 沈降量 $\leqq 2 \mathrm{~mm}$ ) を満足 するものであった。これらのコンクリートについては, CFT 造充填コンクリートとして使用できる可能性が高い。

ブリーディング量は，一般の場合と同様にコンクリー 卜温度が高く，セメント量が多い方が少なくなる傾向が 認められ，凝結時間と深いかかわりがあると考えられる。 これに対して, 沈降量は, 凝結時間やブリーディングに 対する明確な関係は認められなかった。 


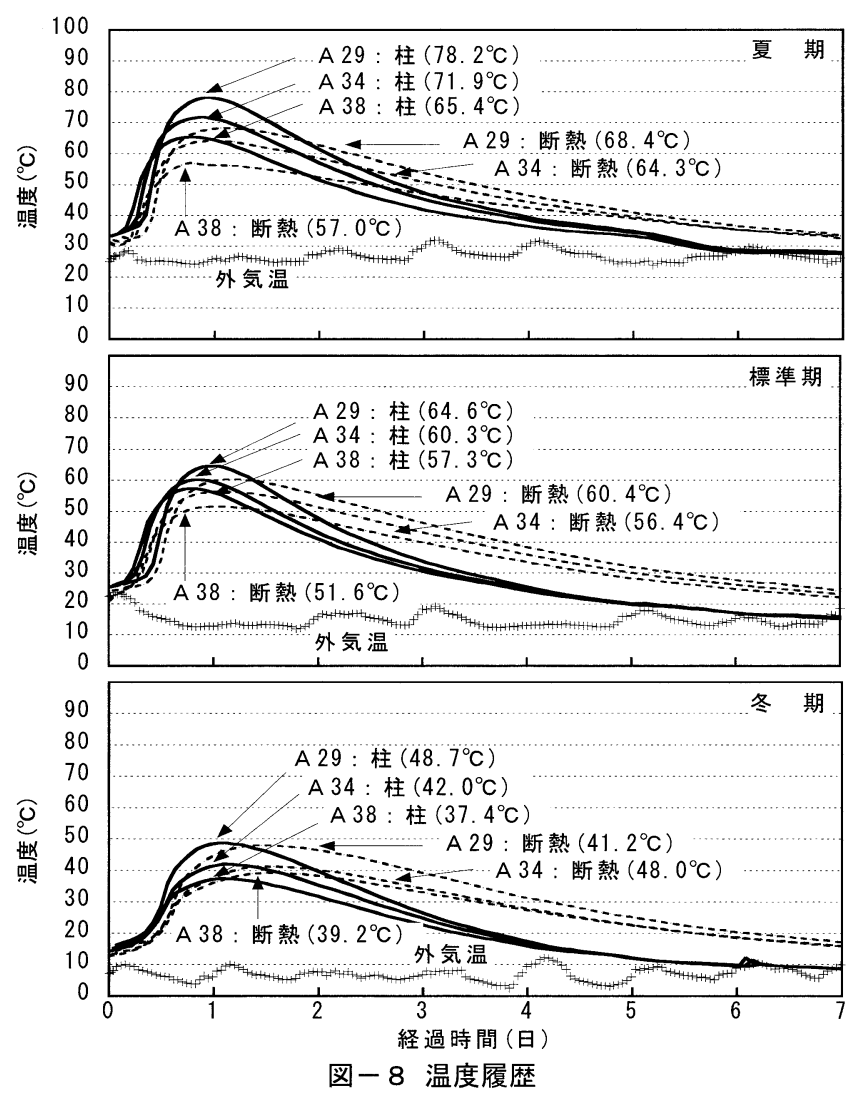

\section{2 部材内部温度}

(1) 温度履歴

実大模擬柱試験体および簡易断熱養生供試体の温度履 歴の一例 (A38,A34,A29) を図－8に示す。実大模擬柱試験 体の最高温度および温度上昇量は，打込み温度が高いほ ど大きく，最高温度到達時間も早かった。簡易断熱養生 の最高温度は, 実大模擬柱中心部よりも低く, 温度降下 速度は遅い傾向にあった。

(2) 最高温度

今回得られたデータから，実大模擬柱 $(900 \times 900 \times$ $\mathrm{H} 1100 \mathrm{~mm})$ および簡易断熱養生供試体の最高温度を目的変 数, 単位セメント量とコンクリート打込み温度を説明変 数として, 重回帰分析を行った結果, 式(1)および式(2) を得た。

実大模擬柱

$$
T_{\max }=0.064 \cdot C+1.480 \cdot T-9.420
$$

簡易断熱養生供試体

$$
T_{\max }=0.054 \cdot C+1.140 \cdot T-0.398
$$

$$
\begin{aligned}
\text { ここで } \quad \mathrm{T}_{\max } & : \text { コンクリート最高温度 }\left({ }^{\circ} \mathrm{C}\right) \\
\mathrm{C} & : \text { 単位セメント量 }\left(\mathrm{kg} / \mathrm{m}^{3}\right) \\
\mathrm{T} & : \text { 打込み時のコンクリート温度 }\left({ }^{\circ} \mathrm{C}\right)
\end{aligned}
$$

式(1)および式 (2)で得られる計算值と実測值の関係を 図ー9に示す。中庸熱ポルトランドセメントの場合にお

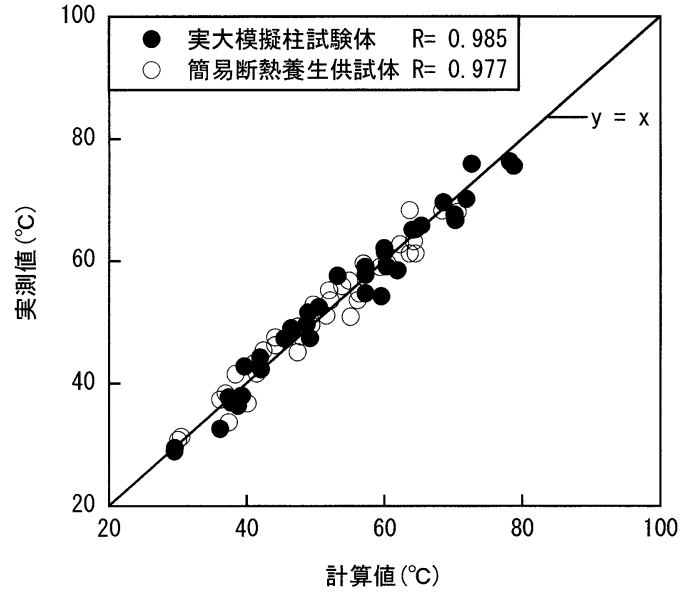

図-9 最高温度計算值と実測值の関係

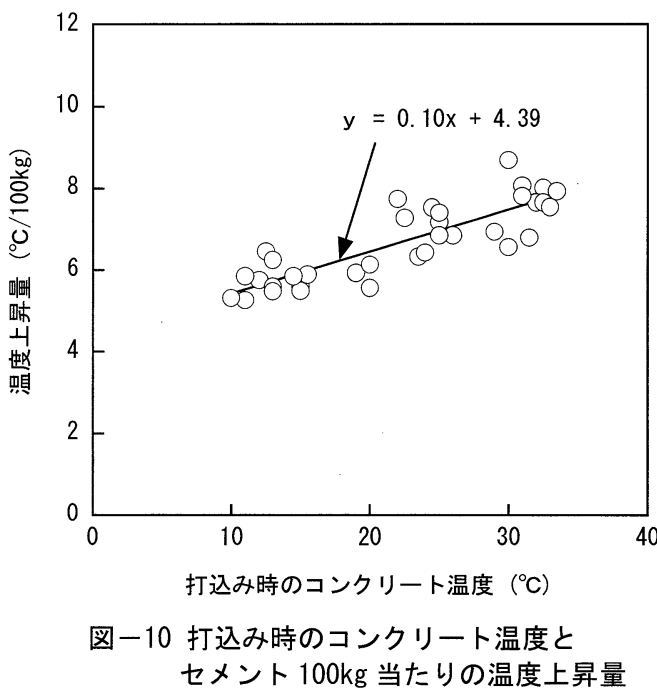

いても，普通ポルトランドセメントの場合と同様，コン クリート構造体内部の最高温度を比較的よく推定できる。 また, 式(1)により求めた中庸熱ポルトランドセメント の最高温度計算值は, 既往の研究 ${ }^{12)}$ にるる普通ポルトラ ンドセメントと比較すると, 部材寸法 $900 \mathrm{~mm}$, 単位セメ ント量 $500 \mathrm{~kg}$, 打込み温度 $20^{\circ} \mathrm{C}$ の時に約 $3.5^{\circ} \mathrm{C}$, 打込み 温度 $30^{\circ} \mathrm{C}$ の時に約 $5{ }^{\circ} \mathrm{C}$ 差がある。

打込み時期で比較すると, 両者の最高温度計算值の差 は，冬期，標準期，夏期の順に大きくなる傾向にある。 このことから，高強度コンクリートの場合においても， 夏期における中庸熱ポルトランドセメントの使用は，一 般のコンクリートの場合と同様に，最高温度を低減する 有効な対策の一つとなると考えられる。

(3) 温度上昇量

打込み時のコンクリート温度とセメント $100 \mathrm{~kg}$ 当たり の温度上昇量の関係を図ー10 に示す。セメント $100 \mathrm{~kg}$ 当 たりの温度上昇量は， $5^{\circ} \mathrm{C} \sim 7^{\circ} \mathrm{C}$ 程度であった。

\section{3 圧縮強度}

（1）強度発現性

標準養生およびコア供試体の強度発現性状を図ー11に 


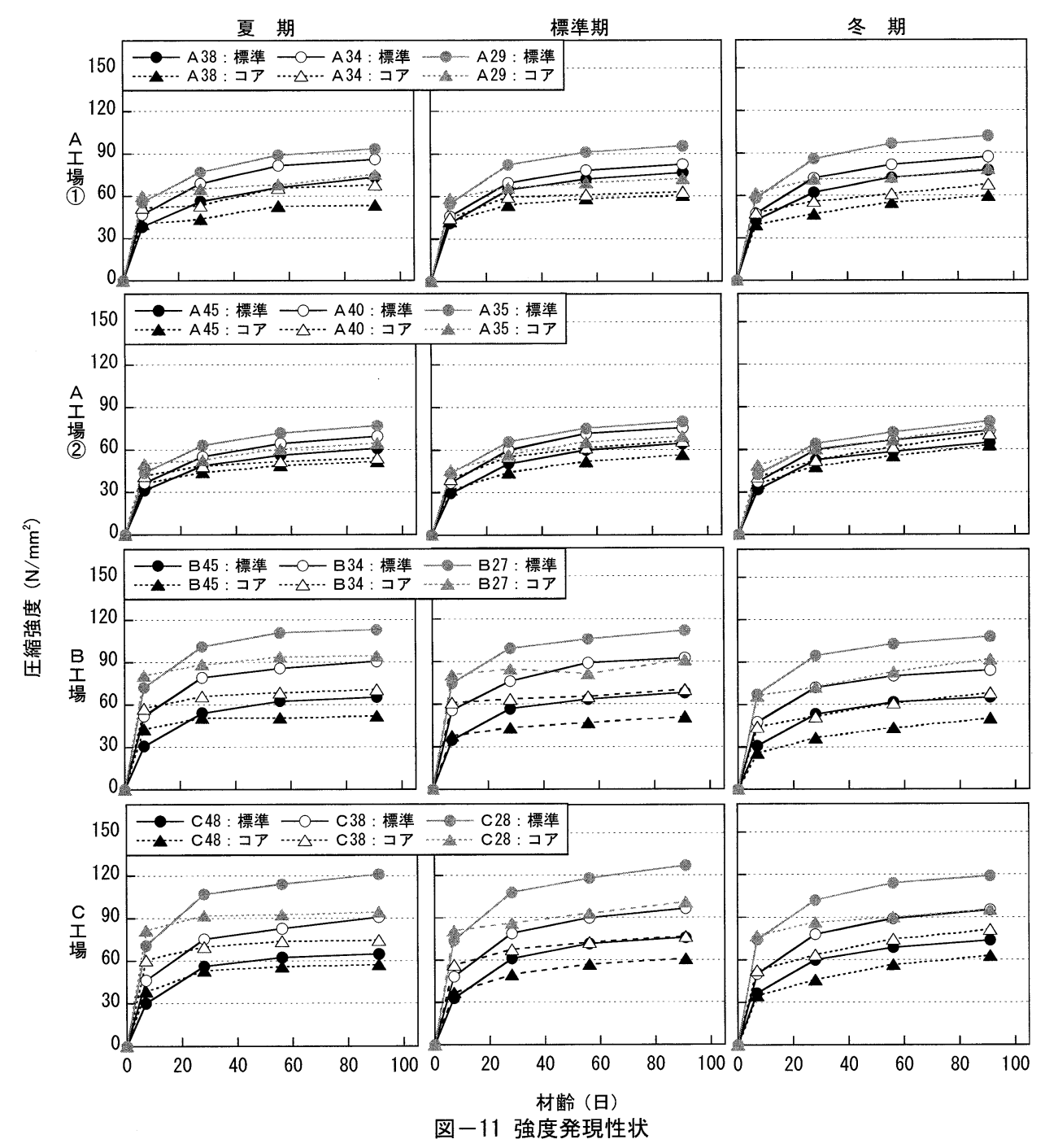

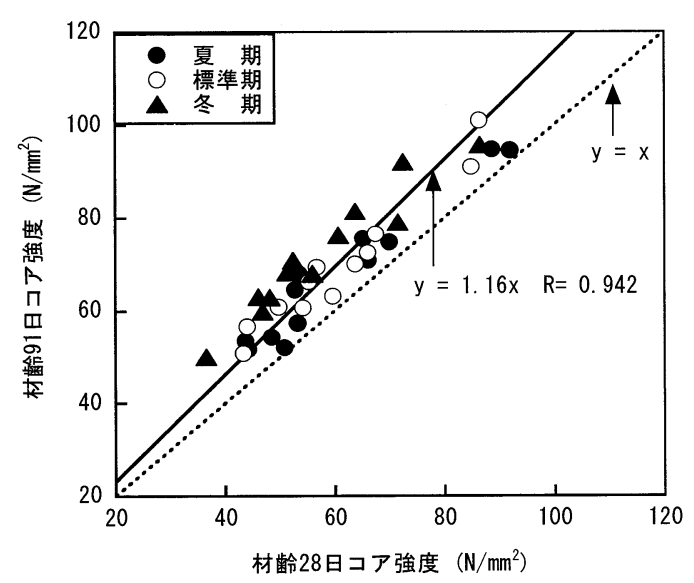

図一12 材齢 28 日と材齢 91 日におけるコア強度の関係

示す。中庸熱ポルトランドセメントを用いた高強度コン クリートにおいては，いずれの調合も，材齢ごとの各打 込み時期における強度差は小さく, 季節変動が強度に与 える影響は小さかった。

材齢 28 日のコア強度と材齢 91 日のコア強度の関係を 図-12 に示す。構造体における材齢 28 日から材齢 91 日 にかけてコア強度は約 1.16 倍に増加した。

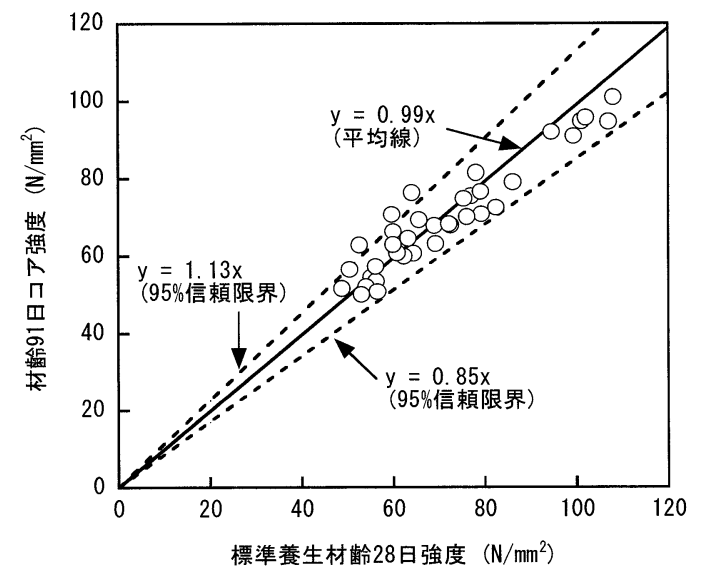

図一13 標準養生 28 日強度と材齢 91 日コア強度

材齢 28 日の標準養生強度と材齢 91 日のコア強度の関 係を図-13 に示す。材齢 28 日の標準養生強度と材齢 91 日のコア強度の関係式は, 普通ポルトランドセメントを 用いた場合 ${ }^{12)}$ とほぼ一致する結果となった。

（2）最高温度と温度上昇量の圧縮強度への影響 最高温度および温度上昇量と標準養生 28 日強度に対す る 91 日コア強度 (以下, 強度比という)の関係を図ー14 

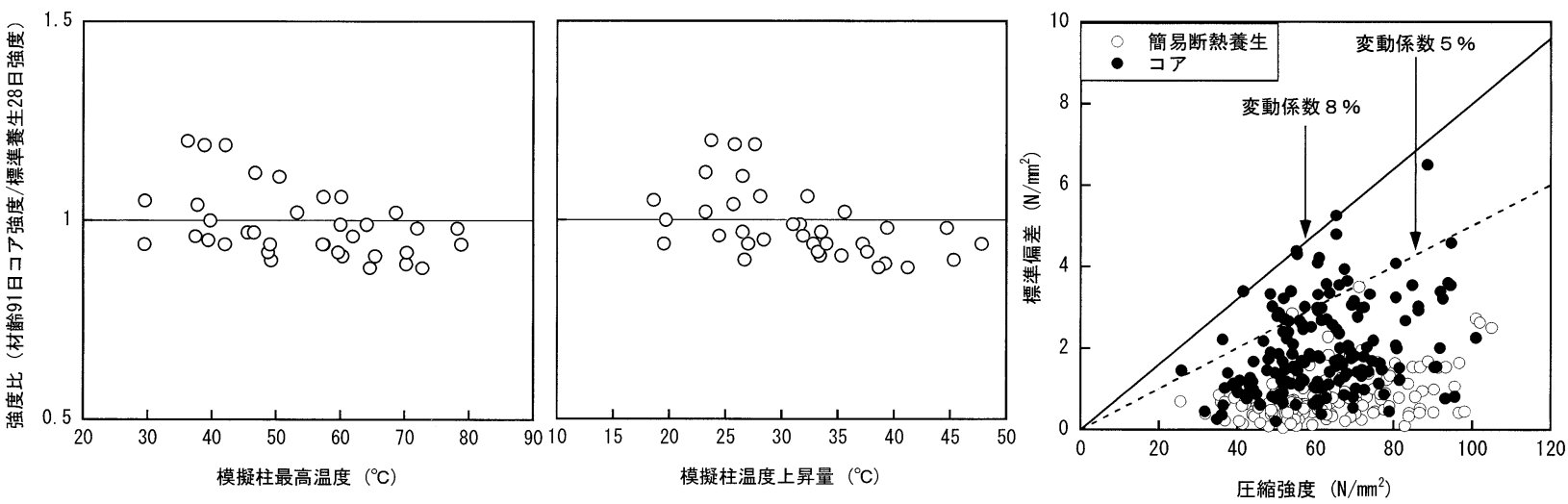

図-14 実大模擬柱最高温度および温度上昇量と標準養生 28 日強度に対する 91 日コア強度 図一15 圧縮強度と標準偏差

に示す。強度比は，模擬柱中心部の最高温度および温度 上昇量が高くなるに従って小さくなる傾向にあり，最高 温度では $60^{\circ} \mathrm{C}$ 程度, 温度上昇量では $35^{\circ} \mathrm{C}$ 程度を境にして 1.0 以下となるものが多い。既往の研究 ${ }^{12)}$ と比較すると, 強度比は普通ポルトランドセメントを用いた場合に近い 結果となった。

（３）コア強度と簡易断熱養生強度の標準偏差

コア強度と簡易断熱養生強度の標準偏差の関係を図一 15 に示す。これを変動係数でみればコア強度は，平均で $3 \%$ ，最大で $8 \%$ であり，簡易断熱養生強度では，いずれ も5\%以下であった。

（4）簡易断熱養生強度とコア強度

簡易断熱養生強度とコア強度の関係を図ー16 に示す。 簡易断熱養生強度とコア強度は，およそ $60 \mathrm{~N} / \mathrm{mm}^{2}$ までは 同程度，これを超える強度ではコア強度の方がわずかで はあるが小さくなる傾向にあった。コア強度が $100 \mathrm{~N} / \mathrm{mm}^{2}$ までの範囲では，今回得られた推定式により，構造体コ ンクリート強度を比較的よく推定できる。また，既往の 研究 ${ }^{7)}$ による推定式を用いることによって，実大模擬柱 試験体からコアを採取することなく簡易断熱養生強度に より，安全側で調合強度を設定できると考えられる。

\section{5. 構造体コンクリート強度を確保するための圧 縮強度と水セメント比の関係}

今回得られた実験データから，中庸熱ポルトランドセ メントを用いた高強度コンクリートの柱部材における設 計基準強度と水セメント比の関係について検討した。

まず，既往の研究 ${ }^{13)}$ と同様に材齢別にセメント水比と コア強度の関係を式 (3) を用いて直線回帰して式 (4), 式 (5)および式(6)を求めた。

$$
F=A(C / W)+B
$$

ここで $F \quad$ : コア供試体の圧縮強度 $A, B$ : 実験定数

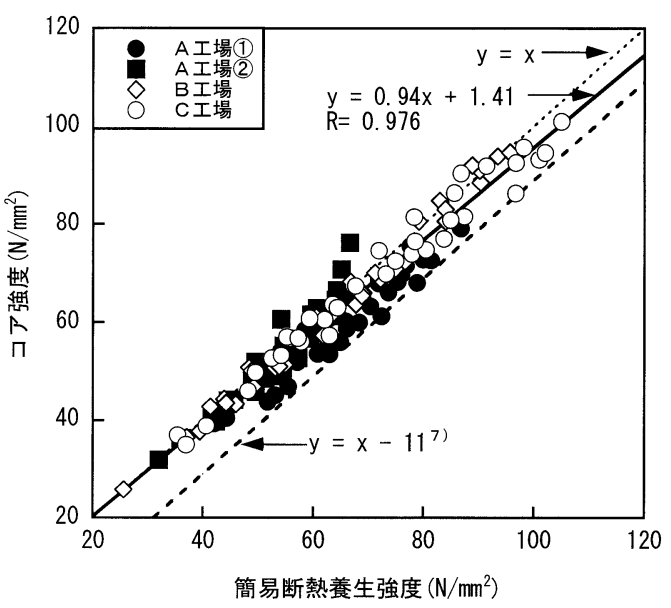

図-16 簡易断熱養生強度とコア強度

材齢 28 日 $\quad F_{28}=23.4 \times(C / W)-6.0$

材齢 56 日 $\quad F_{56}=21.7 \times(C / W)+4.3$

材齢 91 日 $\quad F_{91}=22.7 \times(C / W)+6.0$

次に, 得られた材齢 28 日, 56 日および 91 日での式(4), 式(5)および式(6)の傾き $\mathrm{A}$ を用いて季節別に同様の直線 回帰を行い, 切片 B'を求めた。

また，B’の標準偏差 $\sigma$ を求め，不良率 $5 \%$ に対応する $1.64 \sigma$ を差し引くことにより，この直線の $95 \%$ 信頼限界 を表す直線の切片 B” を求めた。材齢ごとに求めた切片 の一覧を表ー 7 に示す。

\section{表一 7 切片の一覧（単位 : $\mathrm{N} / \mathrm{mm}^{2}$ )}

\begin{tabular}{c|c|c|c|c|c|c}
\hline & \multicolumn{3}{|c|}{ B' (平均線) } & \multicolumn{3}{c}{ B” (95\%信頼限界下限) } \\
\cline { 2 - 7 } & 28 日 & 56 日 & 91 日 & 28 日 & 56 日 & 91 日 \\
\hline \hline 夏 期 & -3.0 & 5.7 & 5.2 & -18.1 & -6.7 & -5.6 \\
\hline 標準期 & -4.9 & 4.3 & 6.1 & -14.2 & -6.4 & -6.2 \\
\hline 冬 期 & -8.2 & 4.1 & 8.4 & -19.2 & -7.3 & -3.5 \\
\hline
\end{tabular}

以上により求めた回帰式を記入したセメント水比とコ ア強度の関係を図ー17 に示す。この結果から構造体コン クリート強度が設計基準強度を満足するための水セメン 卜比が求められ，この際水セメント比とコア強度の回帰 


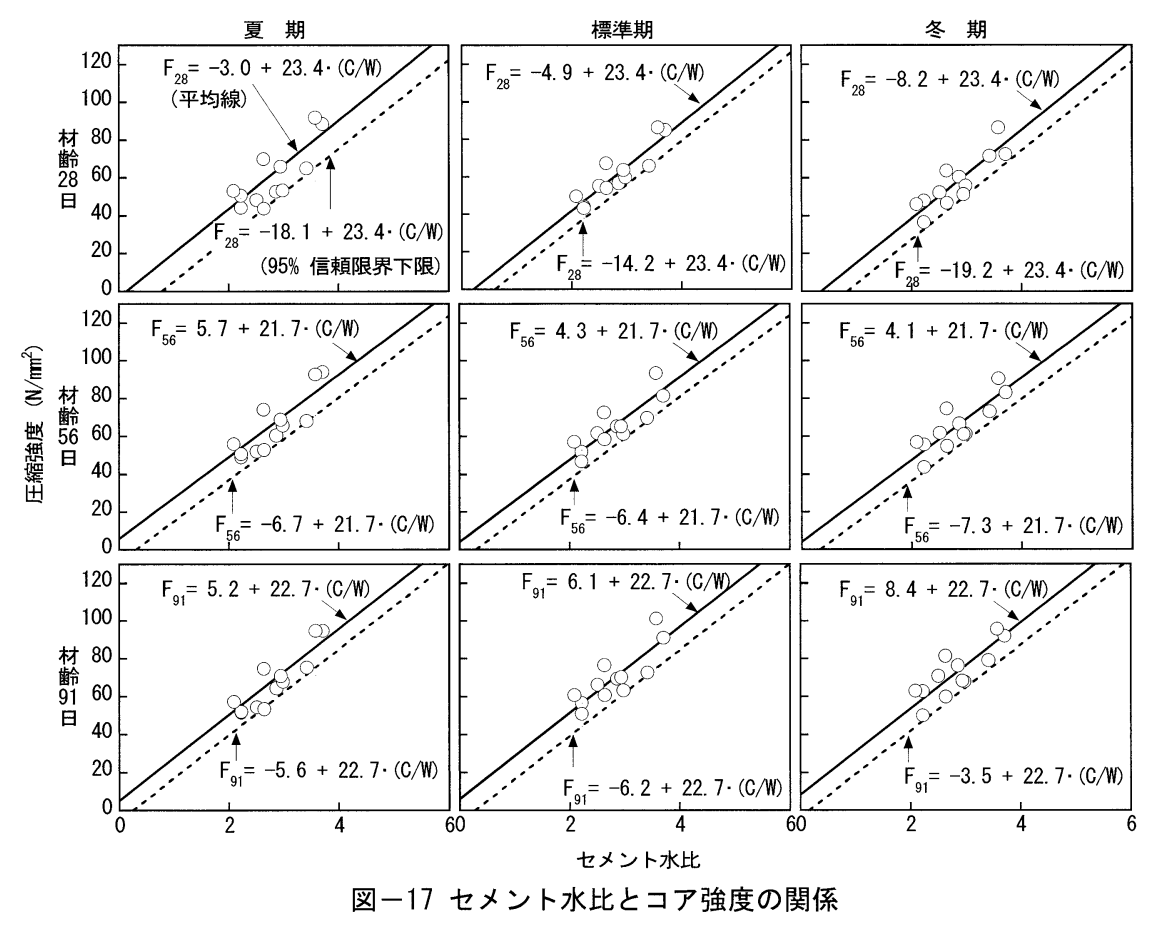

\begin{tabular}{|c|c|c|c|c|c|c|c|c|c|c|c|}
\hline & \begin{tabular}{|c|}
$\begin{array}{c}\text { 設計基準強度 } \\
\left(\mathrm{N} / \mathrm{mm}^{2}\right)\end{array}$ \\
\end{tabular} & 36 & 39 & 42 & 45 & 48 & 51 & 54 & 57 & 60 & 70 \\
\hline \multirow{3}{*}{ 材齢91日 } & 夏 期 & 54.6 & 50.9 & 47.7 & 44.9 & 42.4 & 40.1 & 38.1 & 36.3 & 34.6 & 30.0 \\
\hline & 標準期 & 53.8 & 50.2 & 47.1 & 44.3 & 41.9 & 39.7 & 37.7 & 35.9 & 34.3 & 29.8 \\
\hline & 冬 期 & 57.5 & 53.5 & 49.9 & 46.8 & 44.1 & 41.7 & 39.5 & 37.5 & 35.8 & 30.9 \\
\hline \multirow{3}{*}{ 材齢56日 } & 夏 期 & 50.8 & 47.5 & 44.6 & 42.0 & 39.7 & 37.6 & 35.7 & 34.1 & 32.5 & 28.3 \\
\hline & 標準期 & 51.2 & 47.8 & 44.8 & 42.2 & 39.9 & 37.8 & 35.9 & 34.2 & 32.7 & 28.4 \\
\hline & 冬 期 & 50.1 & 46.8 & 44.0 & 41.5 & 39.2 & 37.2 & 35.4 & 33.7 & 32.2 & 28.1 \\
\hline \multirow{3}{*}{ 材齢28日 } & 夏 期 & 43.3 & 41.0 & 39.0 & 37.1 & 35.4 & 33.9 & 32.5 & 31.2 & 30.0 & 26.6 \\
\hline & 標準期 & 46.6 & 44.0 & 41.6 & 39.5 & 37.6 & 35.9 & 34.3 & 32.9 & 31.5 & 27.8 \\
\hline & 冬 期 & 42.4 & 40.2 & 38.2 & 36.5 & 34.8 & 33.3 & 32.0 & 30.7 & 29.6 & 26.2 \\
\hline
\end{tabular}

今回の実験の範囲 (W/C48〜 27\%) 外

線における下限の 95\%信頼限界を用いれぼほぼ安全側の 值となる。式(4), 式(5)および式(6)の傾きおよび表－7 の切片 B”を用いた 95\%信頼限界の下限式で求めた季節 別による材齢ごとの構造体コンクリート強度が設計基準 強度を満足するための水セメント比を表ー8に示す。

この表から,材齢 91 日における構造体コンクリート強 度が設計基準強度 $70 \mathrm{~N} / \mathrm{mm}^{2}$ を満足するための水セメント 比は $30 \%$ 程度であるため, 前述したように十分に施工可 能と考えられる。

普通ポルトランドセメントを用いた場合 ${ }^{13)}$ と比較する と, 材齢 91 日における構造体コンクリート強度が, 設計 基準強度を満足するための水セメント比は，中庸熱ポル トランドセメントを用いた場合が, $36 \mathrm{~N} / \mathrm{mm}^{2}$ で 6\% 10\% 程度， $70 \mathrm{~N} / \mathrm{mm}^{2}$ で 3\%〜 5\%程度大きかった。

また, 材齢 28 日では, 冬期についてのみ中庸熱ポルト ランドセメントを用いた方が小さかった。これは，冬期 の中庸熱ポルトランドセメントの強度発現性が, 普通ポ ルトランドセメントより小さいことが原因と考えられる。

\section{6. まとめ}

中庸熱ポルトランドセメントを設計基準強度 36 〜 $70 \mathrm{~N} / \mathrm{mm}^{2}$ の高強度コンクリートに適用した場合のフレッ シュ性状, 実大模擬柱部材の温度履歴性状および強度発 現性状について検討した結果に基づき, 構造体コンクリー 卜強度が設計基準強度を満足するための水セメント比と その施工性について考察した結果, 以下の知見が得られ た。

1）本実験の水セメント比の範囲においては，いずれ も良好なフレッシュ性状を示した。

2）水セメント比が $30 \%$ 以上であれば，通常の範囲に おけるポンプ圧送による施工に，また，すべての調 合においてバケット打ちによる施工に十分適用でき ると考えられる。

3）部材内部の最高温度の推定式による比較は, 同一 条件の普通ポルトランドセメントを用いた場合より も低い。 
4）強度発現性については，いずれの調合も，材齢ご との各打込み時期における強度差は小さく, 季節変 動が強度に与える影響は小さかった。

5）簡易断熱養生強度とコア強度は，高い相関を示し， 簡易断熱養生強度を用いてコア強度を推定できる。

6）柱部材の材齢 91 日における構造体コンクリート強 度が設計基準強度を満足するための水セメント比は, 普通ポルトランドセメントを用いた場合と比較して, $36 \mathrm{~N} / \mathrm{mm}^{2}$ で $6 \%$ ～10\%程度， $70 \mathrm{~N} / \mathrm{mm}^{2}$ で $3 \%$ ～5\%程 度大きくなり，設計基準強度 $70 \mathrm{~N} / \mathrm{mm}^{2}$ では $29 \%$ $31 \%$ 程度であった。

以上本実験を通して中庸熱ポルトランドセメントを用 いた高強度コンクリートの構造体コンクリート強度が設 計基準強度を満足するための水セメント比を提示した。

今後は, 今回の 3 工場における試験結果を含め, 更に データ数を蓄積しその精度を高めていきたい。

\section{謝辞}

本実験を行うにあたり，(株）ピーエス三菱 技術研究所 渡邊一弘グループリーダー，中瀬博一研究員，宇部三菱 セメント (株)，（株）東京菱光コンクリート品川工場，関 東宇部コンクリート工業 (株) 豊洲工場，内山コンクリー 卜工業 (株), 竹本油脂 (株), (株) ポゾリス物産, 花王 (株), 山宗化学(株)をはじめ, 多くの方々のご協力を得ました。 ここに付記し，感謝の意を表します。

なお，本研究の実施にあたり，(株)内山アドバンス中 央技術研究所 前所長 奈良禧德氏には，示唆に富んだご 助言を頂きました。同氏は，平成 15 年 7 月に他界され ました。同氏のご助言に感謝するとともに，ご冥福をお 祈りいたします。
1）日本建築学会建築工事標準仕様書・同解説 JASS5 鉄筋コンクリート工 事 p. 435, 2003

2）竹内良ほか: 低熱ポルトランドセメントの暑中コンクリートへの適用, コンク リート工学年次論文集, Vol. 20, №.2, pp. 553-558, 1998. 6

3）坂本健ほか: 低熱ポルトランドセメントを用いた高強度コンクリートの低温 時におけるフレッシュおよび強度発現に関する検討, 日本建築学会大会 学術講演梗概集, pp. 1071-1072, 2002.8

4）宇部三菱セメント(株):技術資料 p. 6

5）(社)セメント協会:セメントの常識 pp. 20-21, 2002

6）鳴瀬浩康・藤井和俊: 中庸熱ポルトランドセメントの高強度コンクリートへ の適用に関する研究, 宇部三菱セメント研究報告, pp. 1-8, №.3, 2002

7）藤井和俊ほか:簡易断熱養生による中庸熱ポルトランドセメントを用いた 高強度コンクリートの構造体強度の推定, 日本建築学会技術報告集, pp. 9-12, 2002.12

8）岩清水隆: 高強度コンクリートの要求性能と関西地区の現状, GBRC, pp. 2-13, 2001. 7

9）中瀬博一ほか: 中庸熱ボルトランドセメントを用いた高強度高流動コンク リートのポンプ圧送性, 三菱建設技報, pp. 37-41, Vol.9, 2001

10）日本建築学会高流動コンクリートの材料·調合・製造・施工指針(案)・同解 説 pp. 25-28, 1997

11）(社)新都市ハウジング協会:CFT 構造技術指針・同解説 構造設計・耐火 設計・施工, p.92, 2000

12）桝田佳寛ほか: 高強度コンクリートの構造体中での強度発現性と調合強 度, 日本建築学会構造系論文集第 537 号, pp. 13〜20,2000.11

13）桝田佳寛ほか: 普通ポルトランドセメントを用いた高強度コンクリートの構 造体における圧縮強度とセメント水比の関係, 日本建築学会大会学術講 演梗概集, pp. 1063-1064, 2002.8

（原稿受理年月日：2004 年 9 月 9 日）

Relationship between Water-cement Ratio and Strength in Structure and Other Properties of High-strength Moderate-heat Cement Concrete By Koji Akisato, Kazutosi Fujii, Hiroyasu Naruse and Torao Kemi

Concrete Research and Technology Vol.16, No2, May 2005

Synopsis: Moderate-heat portland cement has likely been applied to mass concrete where as in this study it is applied to high-strength concrete with a designed strength ranging from 36 to $70 \mathrm{~N} / \mathrm{mm}^{2}$. Fresh properties, strength development and temperature histories of full-scale model specimens of the high-strength concrete have been investigated. It was found that high-strength concrete with moderate-heat cement can be fully applicable to real construction practice on site. Moreover, some important prediction formulas and parameter value were derived: the maximum temperature of the model specimen with parameters of unit cement content and concrete temperatures, relationship between core strength and simplified adiabatic temperatures and a water-cement ratio by which column strengths in structure can satisfy the designed strength.

Keywords: Moderate-heat cement, High-strength concrete, Fresh properties, Compressive Strength, Water-Cement ratio, Workability 